http://dx.doi.org/10.11646/phytotaxa.159.4.3

\title{
A new endemic Ramalina species from the Canary Islands (Ascomycota, Lecanorales)
}

\author{
ISRAEL PÉREZ-VARGAS ${ }^{1} \&$ SERGIO PÉREZ-ORTEGA ${ }^{2}$ \\ ${ }^{\prime}$ Departamento de Biología Vegetal (Botánica), Facultad de Farmacia, Universidad de La Laguna, c/ Astrofisico Sánchez s/n, \\ E-38071 Tenerife, Canary Islands, Spain \\ ${ }^{2}$ Departamento Biología Ambiental, Museo Nacional de Ciencias Naturales (CSIC), c/ Serrano 115-dpdo, E-28006, Madrid, Spain
}

\begin{abstract}
Ramalina alisiosae (Ramalinaceae), found on trees in the laurel forests of the Canary Islands is described as new to science. A description of the species is given together with notes on its chemistry, distribution, ecology, and taxonomy. Bayesian and Maximum Likelihood analyses of ITS sequences showed a close relation of the new species with $R$. implectens and $R$. farinacea. Morphological and anatomical differences with these related lichen taxa are discussed.
\end{abstract}

Key words: Biodiversity, endemism, Macaronesia, Ramalinaceae, taxonomy

\section{Introduction}

Ramalina Nylander in Luyken (1809: 95) is a large genus of cosmopolitan lichens with over 200 species currently recognised (Kirk et al. 2008). Nevertheless, the morphological characters commonly used in its taxonomy show a remarkable plasticity (Boucher \& Nash 1990; Pintado et al.1997) and, in addition, the chemistry is very complex (Krog \& Swinscow 1973; Arroyo Cabeza \& Manrique Reol 1989; Culberson et al. 1993). Often, no correlation between morphological variation and chemical variability can be found, leading to the description of a high number of infraspecific and specific taxa, currently treated as synonyms or chemicals strains (Arroyo et al. 2011). The genus is characterized by a fruticose thallus, erect or pendulous, pale yellow-green, strap-like branches, compressed or terete, solid or fistulose, rarely fenestrate, smooth or reticulate. Soralia, pseudocyphellae or striae are frequent in many species; the cortex is usually thin, supported by a chondroid tissue. The medulla is dense and opaque or more frequently lax and arachnoid. The apothecia are shortly stalked with elongate-clavate asci, which are of the Bacidia-type and 8-spored; ascospores are colourless, 1-septate, broadly ellipsoid or kidney-shaped. The conidiomata are pycnidia with pale or blackened ostiole, conidia bacilliform, colourless, and non-septate (Fletcher et al. 2009, Serusiaux et al. 2010).

The genus Ramalina has received considerable attention during the last decades and several regional monographic treatments have been published (Stevens 1987; Kashiwadani \& Kalb 1993; Blanchon et al. 1996; Aptroot \& Bungartz 2007; Aptroot \& Schumm 2008), including the Canary Islands (Krog \& Østhagen 1980a). The Canaries belong to Macaronesia, one of the 25 World Biodiversity Hotspots (Myers et al. 2000), a phytogeographical region that includes five Atlantic volcanic archipelagoes (the Azores, the Madeiras, the Savages, the Canary Islands and the Cape Verde Islands), as well as the Macaronesian Enclave (Báez \& SánchezPinto 1983; Jaén-Molina et al. 2009) on the African mainland. The lichen biota of the Canary Islands is very rich with more than 1600 species listed for an area of just $7447 \mathrm{~km}^{2}$ (Hernández Padrón \& Pérez-Vargas 2009). Nevertheless, new species continue to be described frequently from this region (e.g. Serusiaux et al. 2007; PérezVargas \& Pérez de Paz 2009; van den Boom 2010; Giralt \& van den Boom 2011; Pérez Vargas et al. 2012) confirming that the lichen biota in this region with its many ecosystems, is still insufficiently known. In the present work we describe a new species of Ramalina from this Archipelago. Because lichens exhibit globally high dispersal capacities (Muñoz et al. 2004), they usually show widespread distributions and endemism is generally 
The fertile Ramalina implectens is closely related to the new species. It is known from Macaronesia and the Southern part of the Iberian Peninsula. It is mainly a corticolous species, although rarely found on rocks. The main distinguishing feature is the absence of soralia in $R$. implectens. In addition, the laciniae do not develop branchlets; the cortex is thinner $(10-15 \mu \mathrm{m}$ vs $25-45 \mu \mathrm{m}$ in $R$. alisiosae); apothecia are numerous and frequently in geniculate branches and spurred; moreover, the spores have a subterminal pseudoseptum (Krog \& Østhagen, 1980a) not seen in $R$. alisiosae and they are larger and wider in the new species.

\section{Acknowledgements}

We are very thankful to Dr. A. de los Ríos (MNCN, CSIC, Madrid) who let us the use of the molecular lab facilities; Dr. M. Arróniz-Crespo for her kind help during field work and Isaac Begoña for his helpful review of the English text.

\section{References}

Acharius, E. (1810) Lichenographia Universalis. Göttingen.

Adanson, M. (1763) Familles des Plantes. Vincent, Paris. http://dx.doi.org/10.5962/bhl.title.271

Akaike, H. (1974) A new look at the statistical model identification. IEEE Transactions on Automatic Control 19: 716-723. http://dx.doi.org/10.1109/tac.1974.1100705

Álvarez, J., Paz-Bermúdez, G. \& Sánchez-Biezma, M.J. (2001) Estudio quimiotaxonómico del género Ramalina Ach. (Lecanorales, Ascomycotina) en Galicia (NW de España). Cyptogamie Mycologie 22: 271-287. http://dx.doi.org/10.1016/s0181-1584(01)01075-2

Aptroot, A. \& Bungartz, F. (2007) The lichen genus Ramalina on the Galapagos. Lichenologist 39: 519-542. http://dx.doi.org/10.1017/s0024282907006901

Aptroot, A. \& Schumm, F. (2008) Key to Ramalina species known from Atlantic islands, with two new species from the Azores. Sauteria 15: 21-57.

Arroyo Cabeza, R. \& Manrique Reol, E. (1989) Estudios químicos del género Ramalina Ach. en el centro de la Península Ibérica. Anales del Jardín Botánico de Madrid 46: 307-315.

Arroyo, R., Seriñá, E. \& Araujo, E. (2011) Ramalina carminae (Ascomycota: Ramalinaceae), a new species from Europe. Botanica Complutensis 35: 5-14. http://dx.doi.org/10.5209/rev_bocm.2011.v35.1

Báez, M. \& Sánchez-Pinto, L. (1983) Islas de Fuego y Agua. Canarias, Azores, Madeira, Salvajes, Cabo Verde. Macaronesia. Edirca Press, Las Palmas de Gran Canaria.

Blanchon, D.J., Braggins, J.E. \& Stewart, A. (1996) The lichen genus Ramalina in New Zealand. Journal of the Hattori Botanical Laboratory 79: 43-98.

Brodo, I., Sharnoff, S.D. \& Sharnoff, S. (2001) Lichens of North America. Yale University Press, New Haven.

Boucher, V.L. \& Nash III, T.H. (1990) Growth patterns in Ramalina menziesii in California: coastal vs. inland populations. Bryologist 93: 295-302. http://dx.doi.org/10.2307/3243516

Culberson, C.F. (1972) Improved conditions and new data for the identification of lichen products by a standardized thin-layer chromatographic method. Journal of Chromatography 72: 113-125. http://dx.doi.org/10.1016/0021-9673(72)80013-x

Culberson, C.F., Culberson, W.L. \& Johnson, A. (1981) A standardized TLC analysis of B-orcinol depsidones. Bryologist 84: 16-29. http://dx.doi.org/10.2307/3242974

Culberson, W.L., Culberson, C.F. \& Johnson, A. (1993) Speciation in lichens of the Ramalina siliquosa complex (Ascomycotina, Ramalinaceae): gene flow and reproductive isolation. American Journal of Botany 80: 1472-1481. http://dx.doi.org/10.2307/2445677

Del Arco Aguilar, M.J., González-González, R., Garzón-Machado, V. \& Pizarro-Hernández, B. (2010) Actual and potential natural vegetation on the Canary Islands and its conservation status. Biodiversity and Conservation 19: 3089-3140. http://dx.doi.org/10.1007/s10531-010-9881-2

Edgar, R.C. (2004). MUSCLE: multiple sequence alignment with high accuracy and high throughput. Nucleic Acids Research 32: 1792-1797. http://dx.doi.org/10.1093/nar/gkh340

Elix, J.A. \& Ernst-Russell, K.D. (1993) A Catalogue of Standardized Thin Layer Chromatographic Data and Biosynthetic 
Relationships for Lichen Substances, 2nd Edn. Australian National University, Canberra.

Fletcher, A. \& James, P.W. \& Purvis, O.W. (2009) Ramalina. In: Smith, C. W., Aptroot, A., Coppins, B. J., Fletcher, A., Gilbert, O. L., James, P. W. \& Wolseley, P. A. (eds.), The Lichens of Great Britain and Ireland British Lichen Society, London. pp. 781-787.

Gardes, M. \& Bruns, T.D. (1993) ITS primers with enhanced specificity for basidiomycetes - application to the identification of mycorrhizae and rust. Molecular Ecology 2: 113-118. http://dx.doi.org/10.1111/j.1365-294x.1993.tb00005.x

Giralt, M. \& Boom, van den, P. (2011) The genus Buellia s.l. and some additional genera of Physciaceae in the Canary Islands. Nova Hedwigia 92: 29-55. http://dx.doi.org/10.1127/0029-5035/2011/0092-0029

Guindon, S., Dufayard, J.F., Lefort, V., Anisimova, M., Hordijk, W. \& Gascuel, O. (2010) New Algorithms and Methods to Estimate Maximum-Likelihood Phylogenies: Assessing the Performance of PhyML 3.0. Systematic Biology 59: $307-321$.

Hafellner, J. (1995) A new checklist of lichens and lichenicolous fungi of Insular Laurimacaronesia including a lichenological bibliography for the area. Fritschiana 5: 1-132.

Hall, T.A. (1999) BioEdit: a user-friendly biological sequence alignment editor and analysis program for Windows 95/98/NT. Nucleic Acids Symposium Series 41: 95-98.

Hernández Padrón, C.E. \& Pérez-Vargas, I. (2009) Lichens, Lichenicolous Fungi. In: Arechavaleta, M., Rodríguez, S., Zurita, N. \& García, A. (eds.), Lista de especies silvestres de Canarias. Hongos, plantas y animales terrestres. Consejería de Medio Ambiente y Ordenación Territorial, La Laguna. pp. 58-84.

Huelsenbeck, J.P. \& Ronquist, F. (2001) MRBAYES, Bayesian inference of phylogenetic trees. Bioinformatics 17: 754-755. http://dx.doi.org/10.1093/bioinformatics/17.8.754

Jaén-Molina, R., Caujapé-Castell, J., Reyes-Betancort, J.A., Hakhani, H., Fernández-Palacios, O., Pérez de Paz, J., FeblesHernández, R. \& Marrero-Rodríguez, A. (2009) The molecular phylogeny of Matthiola R. Br. (Brassicaceae) inferred from IST sequences, with special emphasis on the Macaronesian endemics. Molecular Phylogenetics and Evolution 53: 972-981. http://dx.doi.org/10.1016/j.ympev.2009.08.031

Kashiwadani, H. \& Kalb, K. (1993) The genus Ramalina in Brazil. Lichenologist 25: 1-31. http://dx.doi.org/10.1017/s0024282993000039

Kirk, P., Cannon, P.F., Minter, D.W. \& Stalpers, J.A. (2008) Ainsworth \& Bisby's Dictionary of the Fungi. 10th edn. CAB International, Wallingford, UK.

Klement, O. (1965) Zur Kenntnis der Flechtenvegetation der Kanarischen Inseln. Nova Hedwigia 9: 503-582.

Krog, H. \& Østhagen, H. (1980a) The genus Ramalina in the Canary Islands. Norwegian Journal of Botany 27: $255-296$.

Krog, H. \& Østhagen, H. (1980b) Two new Ramalina species from Porto Santo, the Madeira Islands. Norwegian Journal of Botany 27: 185-188.

Krog, H. \& Swinscow, T.D.V. (1976) The genus Ramalina in East Africa. Norwegian Journal of Botany 23: $153-175$.

Krog, H. (1990) New Ramalina species from Porto Santo, Madeira. Lichenologist 22: 241-247. http://dx.doi.org/10.1017/s0024282990000263

Luyken, J.A. (1809) Tentamen Historiae Lichenum in genere, cui accedunt primae lineae distributionis novae etc. Göttingen.

Muñoz, J., Felicísimo, Á. M., Cabezas, F., Burgaz, A. R., \& Martínez, I. (2004) Wind as a long-distance dispersal vehicle in the Southern Hemisphere. Science 304: 1144-1147. http://dx.doi.org/10.1126/science.1095210

Myers, N., Mittermeier, R.A., Mittermeier, C.G., da Fonseca, G.A.B. \& Kent, J. (2000) Biodiversity hotspots for conservation priorities. Nature 403: 853-858. ttp://dx.doi.org/10.1038/35002501

Nylander, W. (1870) Recognitio monographica Ramalinarum. Bulletin de la Societe Linneenne de Normandie, serie 2 4: 101181.

Nylander, W. (1876) Ramalinae Cubanae novae. Flora (Regensburg) 59: 411-412.

Orange, A., James P.W. \& White, F.J. (2001) Microchemical methods for the identification of lichens. British Lichen Society, London.

Pérez-Vargas, I. \& Pérez de Paz, P.L. (2009) Caloplaca chelyae (Teloschistaceae), a new lichen from the Canary Islands. Bryologist 112: 839-844. http://dx.doi.org/10.1639/0007-2745-112.4.839

Pérez-Vargas, I., Hernández-Padrón, C. \& Pérez de Paz, P.L. (2012) Pertusaria etayoi (lichenized Ascomycota: Pertusariaceae), a new lichen species from the Canary Islands. Lichenologist 44: 333-337. http://dx.doi.org/10.1017/s0024282911000934

Pintado, A., Valladares, R. \& Sancho, L.G. (1997) Exploring phenotypic plasticity in the lichen Ramalina capitata: morphology, water relations and chlorophyll content in north- and south- facing populations. Annals of Botany 80: 345353.

Posada, D. (2008). jModelTest: Phylogenetic Model Averaging. Molecular Biology and Evolution 25: 1253-1256. http://dx.doi.org/10.1093/molbev/msn083

Rambaut, A. \& Drummond, A.J. (2007) Tracer v1.4. Available from http://beast.bio.ed.ac.uk/Tracer. 
Rodriguez, F., Oliver, J.F., Martín A. \& Medina, J.R. (1990) The general stochastic model of nucleotide substitution. Journal of Theoretical Biology 142: 485-501.

http://dx.doi.org/10.1016/s0022-5193(05)80104-3

Serusiaux, E., Berger, F., Brand, M. \& van den Boom, P. (2007) The lichen genus Porina in Macaronesia, with descriptions of two new species. Lichenologist 39: 15-33.

http://dx.doi.org/10.1017/s0024282907005993

Serusiaux, E., van den Boom, P. \& Ertz, D. (2010) A two-gene phylogeny shows the lichen genus Niebla (Lecanorales) is endemic to the New World and does not occur in Macaronesia nor in the Mediterranean basin. Fungal Biology 114: 528537. http://dx.doi.org/10.1016/j.funbio.2010.04.002

Stevens, G.N. (1987) The lichen genus Ramalina in Australia. The Bulletin of the British Museum of Natural History (Botany) 16: $107-223$. http://dx.doi.org/10.1017/s0024282988000234

Stocker-Wörgötter, E., Elix, J. \& Grube, M. (2004) Secondary Chemistry of lichen-forming fungi: chemosyndromic variation and DNA-analyses of cultures and chemotypes in the Ramalina farinacea complex. Bryologist 107: 152-162. http://dx.doi.org/10.1639/0007-2745(2004)107[0152:scolfc]2.0.co;2

Swinscow, T.D.V. \& Krog, H. (1988) Macrolichens of East Africa. British Museum (Natural History), London.

Van den Boom, P.P.G. (2010) Lichens and lichenicolous fungi from Lanzarote (Canary Islands) with the descriptions of two new species. Cryptogamie Mycologie 31: 183-199. http://dx.doi.org/10.7872/crym.v33.iss1.2012.059

White, T.J., Bruns, T., Lee, S. \& Taylor, J (1990) Amplification and direct sequencing of fungal ribosomal RNA genes for phylogenetics. In: Innis, M.A., Gelfand, D.H., Sninsky, J.J. \& White, T.J. (eds.), PCR Protocols: A Guide to Methods and Applications. Academic Press, San Diego. pp. 315-322. 